\title{
KUASA BAJU BEKAS: KODE KULTURAL FESYEN BAJU BEKAS DALAM RANAH INDUSTRI KREATIF
}

\author{
Ayuni Setyaningsih', Nooryan Bahari², Deny Tri Ardiyanto ${ }^{3}$ \\ Prodi Seni Rupa Pascarjana Universitas Sebelas Maret \\ Jl. Ir Sutami No.36A, Jebres, Kec. Jebres, Kota Surakarta \\ Email Korespondensi: ayunideepblue2.as.as@gmail.com
}

\begin{abstract}
ABSTRAK
Fesyen baju bekas menawarkan wilayah kajian yang di dalamnya terdapat tanda, kode, makna. Tulisan ini bertujuan untuk meneliti adanya tanda, pesan, dan makna yang berada dalam baju bekas koleksi Le Budget. Objek kajian baju bekas dibedah dengan menggunakan pendekatan semiotika untuk analisis pemakaian tanda dan maknanya. Teori semiotika digunakan sebagai analisis penelitian untuk mengidentifikasi dan mengklasifikasi bentuk-bentuk tanda pada baju bekas ke dalam tanda tipe ikon, indeks, dan simbol. Melalui analisis bentuk-bentuk tanda pada baju bekas ditemukan kode-kode kultural dan makna yang dikonstruksi. Hal ini menjadi penting karena dalam era industri kreatif ini, fesyen baju bekas Le Budget telah membentuk subkultur anak muda yang dapat menjadi budaya tanding terhadap budaya besar.
\end{abstract}

Kata kunci: Fesyen, Baju Bekas, Semiotika, Industri Kreatif.

\begin{abstract}
Secondhand fashion offers an area of study which there is a sign, code, meaning. This paper aims to examine the sign, messages, and meanings that are in Le Budget's secondhand collection. The secondhand fashion will be dissected by using semiotic approach to analysis the use of sign and its meaning. Semiotic approach is used as a research analysis to identify and classify signs on used shirts into icons, indexes and symbols. Through the analysis of forms of marks on used clothes found cultural codes and constructed meanings. This is important because in this era of creative industry, Le Budget's secondhand have formed a youth subculture that can be a culture of match againts great culture.
\end{abstract}

Keywords: Fashion, Secondhand Clothes, Semiotic, Creative Industry. 


\section{PENDAHULUAN}

"I speak through my cloth". Begitu ungkapan yang populer dari Umberto Eco. Disadari atau tidak, fesyen dapat menjadi suatu pernyataan yang mencerminkan perbedaan status, dan sebagai sarana untuk menunjukkan asal kelompok tertentu dengan sekumpulan idealisme tertentu pula (Barnard, 2011). Fesyen merupakan salah satu hal yang paling penting tentang identitas seseorang. Sebab fesyen mempunyai cara nonverbal untuk memproduksi serta mempertukarkan makna dan nilai-nilai. Fesyen menjadi sebuah bentuk ekspresi individualistik yang digunakan individu untuk membedakan dirinya sendiri sebagai individu dan menyatakan beberapa keunikannya. Konsekuensi logis dari hal tersebut adalah semakin meningkatnya konsumsi dan kebutuhan akan fesyen. Selain itu, fesyen menjadi salah satu objek konsumsi penting dalam masyarakat modern karena merupakan kebutuhan primer bagi setiap manusia. Oleh karenanya kebutuhan akan fesyen atau pakaian jadi terus meningkat seiring perkembangan populasi dunia. Dalam dunia modern, fesyen dapat ditafsirkan sebagai era sejarah yang ditandai dengan inovasi terus-menerus. Industri pakaian jadi dunia terus berkembang diikuti oleh berkembangnya perdagangan internasional. Namun demikian, pada beberapa dekade, muncul isu mengenai baju bekas yang didasari oleh berbagai macam alasan. Awalnya peredaran baju bekas adalah ditujukan untuk hibah bagi korban bencana alam ataupun perdagangan biasa seperti lelang baju bekas artis atau sekedar mencari keuntungan dengan harga murah. Produk baju bekas menjadi salah satu alternatif membentuk suatu gaya baru yang bersaing dengan produk fast fashion, karena dianggap sebagai produk yang ramah lingkungan. Produk fast fashion memberikan banyak dampak negatif seiring dengan meningkatnya kebutuhan sandang terutama bagi kalangan yang ingin tampil modis (Sunhilde, 2012). Isu perdagangan baju bekas tersebut sudah merebak di berbagai negara di dunia, baik di negara maju maupun negara berkembang, termasuk Indonesia.

Namun demikian, isu yang muncul mengenai baju bekas tersebut memberikan dampak negatif bagi negara berkembang seperti Indonesia, yang seolah-olah menjadi penadah bagi pakaian bekas yang sudah tidak dipakai di negara maju. Belum lagi ditambah dengan isu-isu tentang kebersihan dan kesehatan yang menyertai baju-baju bekas tersebut. Di tengah-tengah isu negatif fenomena baju bekas tersebut, terdapat satu hal yang mengusik pemikiran, yakni bahwa dalam kenyataannya masih ada konsumenkonsumen yang tetap setia membeli dan menggunakan produk-produk baju bekas tersebut untuk direproduksi lagi. Reproduksi disini bukan hanya dalam memanfaatkan lagi barang lama untuk dipakai lagi, tetapi ada makna tersembunyi di balik itu. Baju bekas memiliki histori oleh pemiliknya yang lama, ketika baju itu dipakai lagi histori lama ditinggalkan dan mulai membentuk histori baru. Memperpadukan gaya baju lama sehingga membentuk gaya fesyen baru.

Berdasarkan latar belakang di atas, penelitian ini akan mengkaji fenomena baju bekas dengan pendekatan semiotika Charles Sanders Pierce. Baju bekas dipandang sebagai sebuah teks budaya. Teks adalah produk dari tindak penggunaan dan pertukaran tanda. Teks adalah wujud penggunaan seperangkat tanda dalam kehidupan sosial, yang dikombinasikan dengan cara kode tertentu. Teks merupakan pesan-pesan yang menggunakan tanda verbal ataupun visual (Piliang, 2012). Lewat sudut pandang inilah baju bekas dapat dibaca dan ditafsirkan maknanya. Kemungkinan tersebut membuka 
peluang untuk dikaji lebih mendalam lagi karena dapat mengungkapkan bagaimana sebenarnya fenomena baju bekas ini tetap eksis di kalangan penggunanya, kemudian mencaritahu dan menganalisis bagaimana proses terbentuknya kode kultural terhadap fesyen baju bekas, serta menganalisis bagaimana implikasi kode kultural tersebut dalam industri kreatif, khususnya fesyen masa kini.

\section{METODE PENELITIAN}

\section{Jenis dan Bentuk Penelitian}

Penelitian ini berfokus pada mengkaji tentang produksi makna (kode kultural) yang terjadi pada fenomena fesyen baju bekas. Berdasarkan permasalahan tersebut, maka strategi pendekatan dalam penelitian ini menggunakan metode analisis data kualitatif. Pendekatannya tepat untuk memberi peluang bagi upaya pemahaman dan penjelasan kualitatif atas fesyen baju bekas secara lebih mendalam. Selain itu, metode kualitatif lebih mampu mendekatkan peneliti dengan objek fesyen baju bekas yang dikaji.

\section{Lokasi dan Waktu Penelitian}

Penelitian tentang objek kajian fesyen baju bekas ini dilakukan di Yogyakarta karena banyak penjual baju bekas dan terdapat komunitas yang hobi membeli dan mengkoleksi baju bekas. Batasan spasial penelitian ini adalah fesyen baju bekas yang dikoleksi oleh Le Budget di Yogyakarta, sedang batasan temporal adalah antara bulan September 2016 sampai bulan Januari 2017. Pembatasan ini didasarkan atas masalah yang terkait tentang koleksi fesyen baju bekas Le Budget dan beberapa faktor yang mempengaruhi perkembangannya.

\section{Sumber Data Penelitian}

Sumber data penelitian ini terdiri atas sumber data primer dan sekunder. Sumber data primer diperoleh melalui pengamatan langsung dan wawancara. Wujud data primer dalam penelitian ini berupa informasi lisan dan tindakan subjek penelitian. Berikut beberapa narasumber dalam penelitian ini:

a. Diandra Clara, selaku kolektor, pelaku bisnis baju bekas dan pemakai.

b. Widya Rosena, selaku pendiri Hello Market Solo dimana itu adalah sebuah payung yang menaungi berbagai kegiatan yang berhubungan dengan perdagangan baju bekas sekaligus komunitas-komunitas pecinta baju bekas.

Data sekunder diperoleh dari bahan informasi secara tidak langsung. Data yang dimaksud bersumber dari arsip-arsip karya, dokumen-dokumen pribadi, dokumen resmi, foto, gambar dan catatan yang relevan untuk mengungkap permasalahan dalam penelitian. Sumber data sekunder dalam penelitian ini berupa buku-buku, berita media 
cetak, jurnal, dokumen-dokumen, dan hasil penelitian terdahulu yang berkaitan dengan fesyen baju bekas.

\section{Teknik Cuplikan}

Fokus cuplikan dalam penelitian kualitatif ini adalah dengan teknik cuplikan (sample) bersifat purposive, karena dipandang lebih mampu menangkap kelengkapan dan kedalaman data. Dalam penelitian ini tujuan sampling bersifat internal (internal sampling), artinya sample tidak mewakili populasi atau tidak merumuskan karakteristik populasi, tetapi mewakili informasi yang mendalam dan generalisasinya mengarah kepada generalisasi teoritis. Sample yang digunakan dalam penelitian ini adalah koleksi baju bekas dari Diandra Clara.

\section{Teknik Analisis Data}

Semua data tentang perwujudan, bentuk, dan gaya fesyen baju bekas, yang terdiri dari catatan lapangan, foto, artikel, hasil wawancara, dan lain lain akan dianalisis menggunakan teknik analisis data interaktif dari Miles dan Huberman. Model ini didasari oleh tiga langkah alur kegiatan, yaitu reduksi data, penyajian data, dan penarikan kesimpulan atau verifikasi (Miles \& Huberman, 1992:16).

\section{HASIL DAN PEMBAHASAN}

Untuk mengawali hasil dan pembahasan penelitian ini, perlu kiranya terlebih dahulu diperkenalkan dan dijelaskan mengenai Le Budget. Le Budget adalah sebuah online shop yang bergerak di bidang fesyen anak muda, khususnya wanita. Pemilik, sekaligus perintisnya adalah Diandra Clara atau yang akrab disapa dengan panggilan Diandra. Inti dari usaha Le Budget adalah dalam bidang fesyen baju bekas. Bisnis Le Budget ini dimulai saat Diandra masih kuliah di Solo, yakni sekitar tahun 2010. Diandra yang kini berdomisili di Jakarta, memgembangkan bisnis Le Budget dan menyediakan berbagai macam fesyen wanita seperti dress, rok, jaket, serta beberapa aksesoris seperti sepatu dan tas.

Awal mula usaha ini adalah berasal dari hobi Diandra yang suka membeli dan mengenakan baju-baju bekas. Sejak kecil Diandra sudah terbiasa dibelikan barangbarang (mainan, baju, dan lain-lain) second atau bekas oleh orang tuanya. Kebiasaan ini kemudian terbawa hingga dewasa dan mempengaruhi pemilihan fesyen Diandra. Pendapat Diandra, fesyen baju bekas dipandang unik dan menarik karena bertema jadul atau kuno dan bersifat eksklusif sehingga tidak ada yang menyamai. Selain itu, baju bekas memiliki kualitas yang lebih bagus daripada baju keluaran baru. Baju-baju bekas tersebut diperoleh dari pasar loak, seperti misalnya di pasar Senen dan Tanah Abang Jakarta. Biasanya Diandra mendapatkan baju bekas yang berasal dari Amerika dan Korea Selatan. Hobi Diandra tersebut membuat koleksi baju-baju bekasnya semakin hari semakin banyak dan menumpuk, sehingga kemudian muncul ide untuk menjual kembali baju-baju tersebut. Ide tersebut kemudian didorong dengan keyakinan Diandra bahwa menjual baju baru adalah sebuah kriminal, karena sama saja dengan menipu 
konsumen. Harganya mahal namun kualitas biasa saja, bahkan mungkin kualitas rendah. Lahirlah kemudian usaha jual beli fesyen baju bekas Le Budget. Kegiatan jual-beli Le Budget hampir sebagian besar dilakukan secara online. Ketemu pembeli hanya untuk mengantarkan barang pesanan dan menerima pembayaran atau sering disebut dengan istilah COD (cash on delivery). Untuk pembeli dari luar kota, biasanya dilakukan pengiriman melalui jasa pengiriman. Diandra memanfaatkan media sosial instagram sebagai lapak tempat memasarkan koleksi baju bekasnya. Nama akun instagramnya adalah sama, yakni Le Budget. Akun tersebut dapat diakses melalui alamat website www.instagram.com/lebudget.

Berkat konsistensi dan respon yang cepat terhadap pembeli, Le Budget telah berhasil membuat para konsumen-konsumen loyal terhadap brand. Terbukti dengan follower akun instagramnya yang kini mencapai 2000 lebih. Diandra menggunakan sistem penjualan yang mirip dengan flash sale, namun tanpa ada stok ulang barang, mengingat baju-baju yang dijualnya memang hanya satu dari setiap jenisnya. Setiap akan mengupload koleksi jualan, Diandra selalu memberi aba-aba terlebih dahulu kepada calon-calon pembeli, sehingga pada saat diupload peminat dapat segera melakukan order. Siapa cepat, dia yang dapat. Para pembelinya kebanyakan adalah para wanita muda yang berasal dari berbagai daerah di Indonesia.

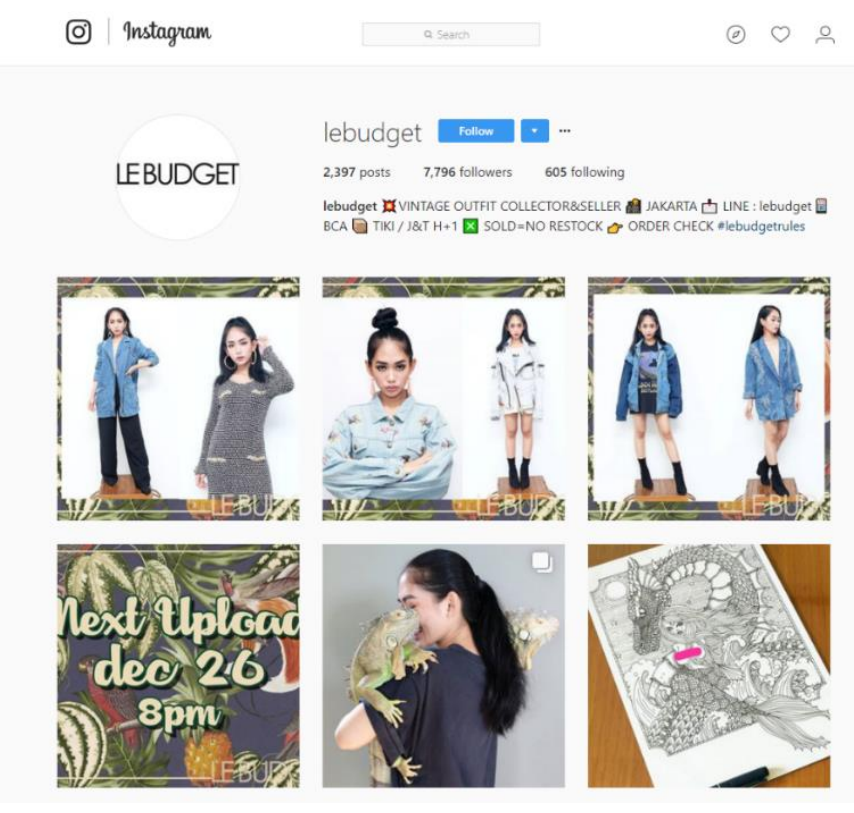

Gambar 1. Tampilan Halaman Akun Instagram Le Budget

Sumber: www.instagram.com/lebudget

\section{Bentuk dan Jenis Koleksi Fesyen Baju Bekas Le Budget}

Barang koleksi adalah benda atau objek yang bernilai sepadan untuk dikumpulkan berkat sebuah passion yang disebut dengan kepemilikan (possession) (Baudrillard, 1994). Sebuah benda atau objek, apabila dinetralkan dari semua konteks, dibebaskan dari aspek fungsinya, maka objek tersebut menjadi murni dan sederhana. Ketika objekobjek tersebut dilepaskan dari aspek fungsionalitasnya, makna dari objek tersebut 
kemudian sepenuhnya bergantung pada sang subjek. Takdir benda-benda tersebut adalah menjadi barang koleksi.

Pada dasarnya, manusia memiliki keinginan untuk mengumpulkan sesuatu sejak masa kanak-kanak. Kepemilikan atas benda-benda tersebut memberikan rasa nyaman bagi sang pemilik. Mereka mendapatkan kenikmatan besar dari upaya menghabiskan energi demi mencari barang langka yang ingin dikoleksi. Saat barang tersebut berhasil didapat, ada sensasi tersendiri yang orang lain tak rasakan. Apapun benda atau objeknya, bahkan yang sepele seperti karpet, meja, kompas. Termasuk diantaranya adalah koleksi fesyen baju bekas dari Le Budget.

Diandra, pemilik Le Bugdet, mengkoleksi baju-baju bekas yang didapat dari pasar loak. Kegiatan mengkoleksi baju bekas tersebut merupakan sebuah pengalaman yang murni menyenangkan dan mengesankan. Diandra mengkoleksi demi mendapatkan rasa senang dari proses mencari, seperti mencari harta karun. Mencari sebuah baju yang unik dan kemudian memperjuangkan untuk bisa mendapatkannya, adalah suatu pengalaman yang mengasyikan. Fesyen baju bekas koleksi Le Budget terdiri dari pakaian-pakaian atas seperti jaket, dress, rompi, kaos, dan kemeja. Jaket atau fesyen luaran seperti jas dan sweeter merupakan barang yang paling banyak dikoleksi. Namun sejalan usahanya yang terus berkembang, kini Le Budget juga mengkoleksi dan menjual pakaian-pakaian bawah seperti rok, celana panjang, celana pendek, dan aksesoris fesyen seperti sepatu dan tas.

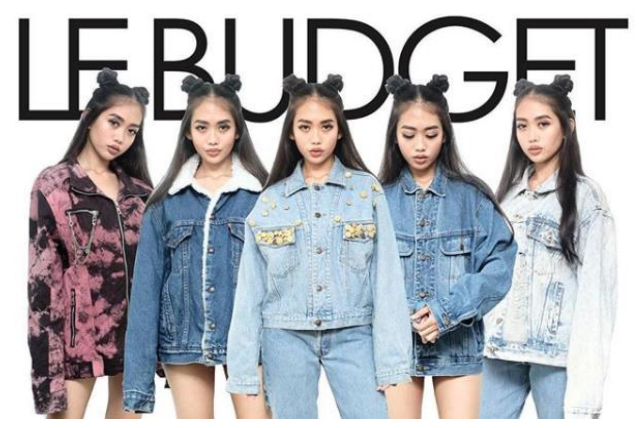

Gambar 2. Koleksi-Koleksi Baju Bekas Le Budget (Diandra) Sumber: Dokumentasi Diandra Clara

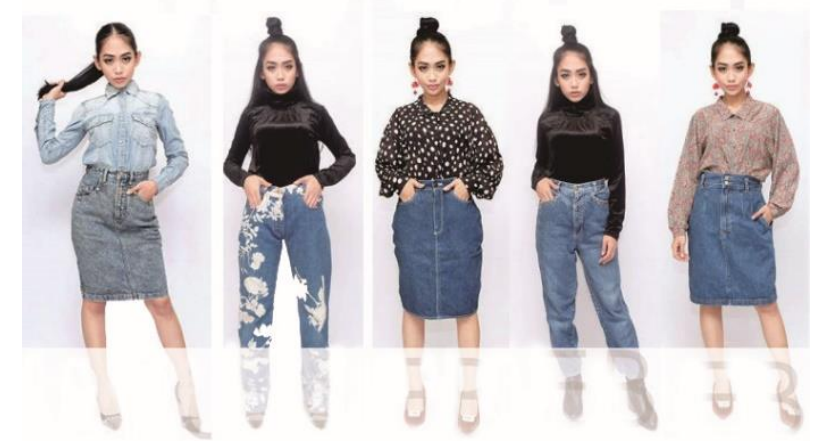

Gambar 3. Koleksi-Koleksi Baju Bekas Le Budget (pakaian bawah) Sumber: Dokumentasi Diandra Clara 

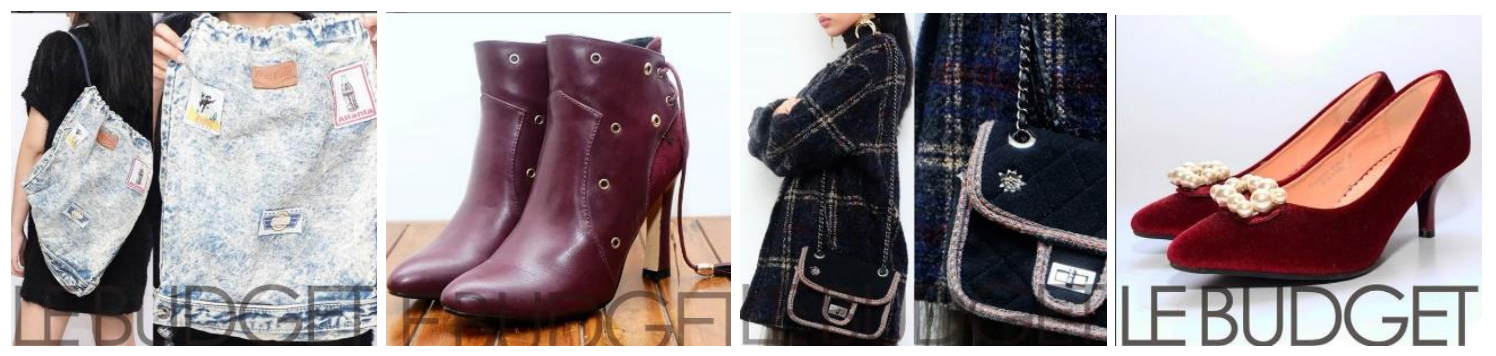

Gambar 4. Koleksi-Koleksi Baju Bekas Le Budget (aksesoris fesyen) Sumber: Dokumentasi Diandra Clara

Ada beberapa alasan kenapa Diandra Le Budget lebih menyukai baju bekas daripada yang baru hingga menjadi seorang kolektor baju bekas. Pertama, membeli baju bekas merupakan suatu pilihan yang lebih ramah lingkungan. Kedua, baju-baju bekas terbukti memiliki kualitas tinggi dan proses produksi hingga finishing yang sangat baik, sehingga mampu bertahan terhadap kemungkinan-kemungkinan buruk selama pemakaian. Ketiga, baju bekas bersifat eksklusif karena tidak ada yang menyamai. Keempat, karena sebenarnya tren fesyen seperti roda yang berputar. Gaya dan tren fesyen hari ini dan esok, akan mengambil inspirasi dari tren fesyen masa lalu dan selalu berputar lagi.

\section{Analisis Semiotis Fesyen Baju Bekas Le Budget}

Dalam pembacaan kode kultural disini, fesyen baju bekas dianggap bukan hanya sebagai artefak semata, melainkan juga sebagai teks yang dapat dibaca dan ditafsir ulang. Untuk bisa mengkaji bagaimana kode-kode kultural baju bekas terbentuk melalui kombinasi seperangkat tanda, digunakan teori semiotika. Semiotika yang digunakan adalah pendekatan khusus yang menekankan aspek-aspek seni dan desain dalam kaitannya dengan daya tarik estetik.

Fesyen baju bekas dianggap sebagai suatu sistem penandaan, karena fesyen baju bekas merupakan karya seni yang diolah si pemakai dan dapat dibaca atau ditafsir ulang oleh penerima tanda. Pendekatan semiotika digunakan untuk mencaritahu tanda-tanda apa saja yang terdapat di dalam fesyen baju bekas tersebut. Langkah selanjutnya, untuk menelisik tanda dan makna fesyen baju bekas le budget, penulis berusaha dengan cara memecah visual fesyen baju bekas menjadi beberapa bagian yang membentuknya (ikon, indeks, simbol), kemudian mencari tanda-tanda yang tersirat di dalamnya untuk menangkap pesan keseluruhan. Lewat analisis tersebut dapat diketahui bagaimana kodekode kultural diproduksi dengan lebih jelas sehingga akan membantu mengungkap pesan atau makna dari fesyen baju bekas tersebut. Untuk pemaparan lebih jelas, dapat disimak pada tulisan berikut. 


\section{Leather Biker Jacket}

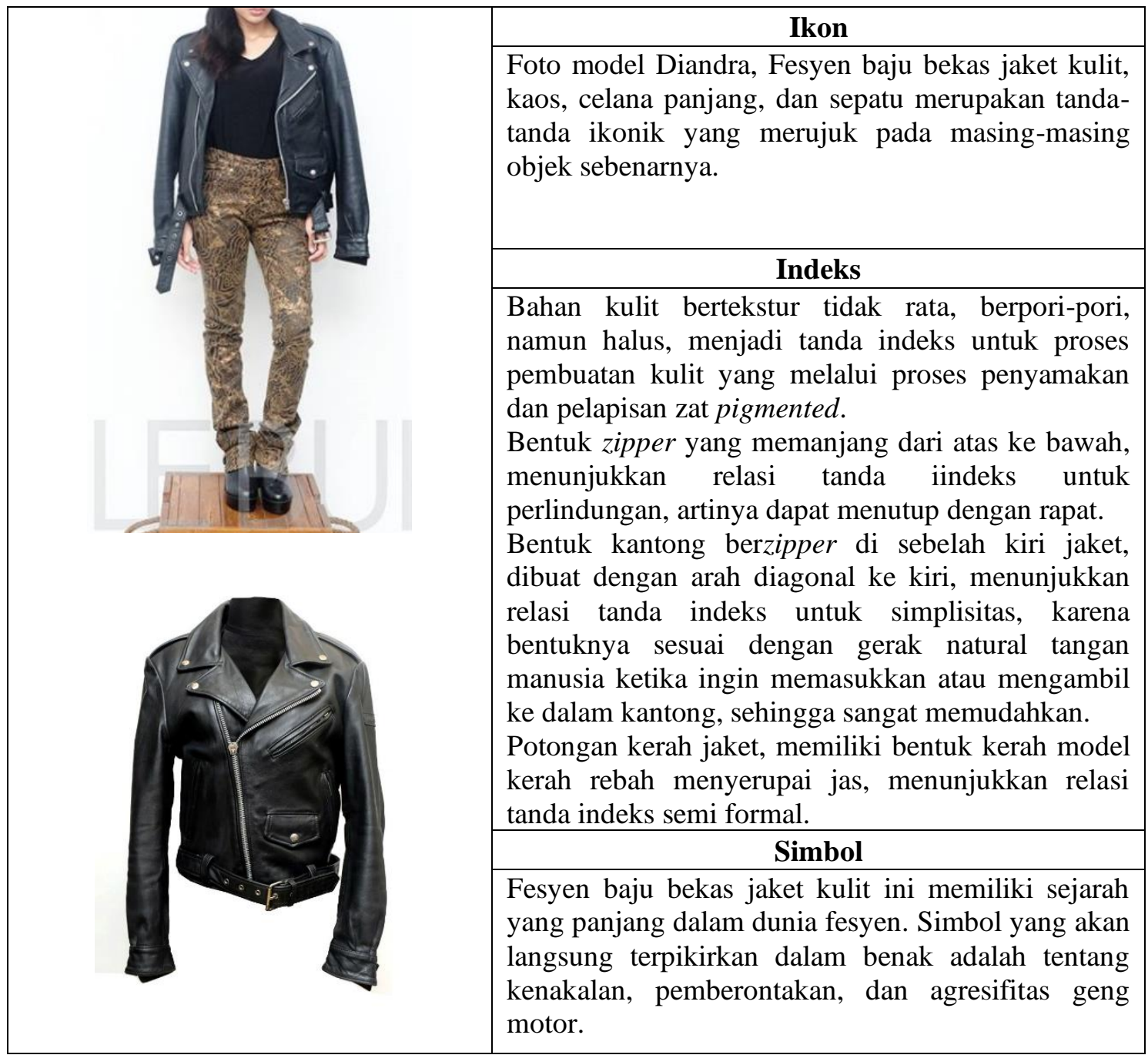

Pada fesyen ini terdapat hal yang cukup menarik perhatian, yakni jaket kulit untuk fesyen wanita. Sebagaimana yang telah dijelaskan sebelumnya, jaket kulit merupakan sinonim untuk pemberontakan, bahaya, kejahatan, dan yang paling penting adalah, lakilaki. Jaket kulit adalah pakaian laki-laki. Awalnya jaket kulit merupakan pakaian untuk pilot dan tentara. Sampai akhir tahun 1940an, jaket kulit masih sering diasosiasikan dengan militer. Seiring berjalannya waktu, jaket kulit mulai dipopulerkan untuk wanita oleh Harley Davidson. Jaket kulit yang lebih sesuai untuk wanita diperkenalkan di katalog aksesoris mereka pada tahun 1954, disebut dengan Ladies Companion Jacket atau sekarang lebih terkenal dengan nama Cycle Queen. Jaket kulit tersebut dibuat untuk para wanita agar dapat berpakaian serasi dengan laki-lakinya namun dengan rasa yang lebih feminim. Sejak saat itu, bagi para wanita yang berani mengenakan jaket kulit diidentikkan dengan wanita nakal dan pemberontak. Selanjutnya kesan nakal dan pemberontak ini diadopsi oleh para artis, grup band punk, dan rock $n$ roll tahun 60an, seperti Elvis Presley dan The Beatles. Tidak semata-mata diadopsi, kesan nakal dan pemberontak berubah menjadi kesan keren (cool). 
Menurut penulis tanda keren ini juga ditambah dengan seringnya jaket kulit muncul dan menjadi ikon dalam film-film box office. Misalnya dalam film trilogi The Matrix, jaket kulit tampil menjadi 'baju perang' sang aktor utama Neo (Keanu Reeves). Lain lagi dalam film Fight Club, jaket kulit merepresentasikan surealitas pertarungan berdarah oleh Tyler Durden (Brad Pitt). Begitu juga si pengantin perempuan dalam Kill Bill, membunuh musuh-musuhnya dalam balutan fesyen jaket kulit. Logan, si makhluk mutan Wolverine, selalu memakai jaket kulit coklatnya yang khas. Kesemua aksi-aksi film tersebut menampilkan ikon jaket kulit secara proporsional sebagai motif utama film. Terlepas dari semua signifikasi jaket kulit di atas, menurut penulis, sekarang wanita yang mengenakan jaket kulit mencari sesuatu yang lain lagi. Wanita berjaket kulit lebih cenderung menjadi wanita yang posmodern. Dalam artian, apa yang mereka pakai adalah untuk praktek pastiche. Dari jaket kulit yang menjanjikan sebuah aksi, pelarian diri dan petualangan, bertransformasi menjadi lebih lunak. Sekarang seorang wanita dapat mengenakan jaket kulit, apalagi berwarna hitam, tanpa perlu tergabung dalam sebuah geng motor, tanpa perlu menjadi rock star, dan tanpa perlu menjadi artis. Jaman sekarang orang mengenakan jaket kulit untuk merepresentasikan tanda autentikasi, yang didapat dari mengenakan sebuah jaket kulit penuh sejarah.

\section{Red Outer NOV-54}

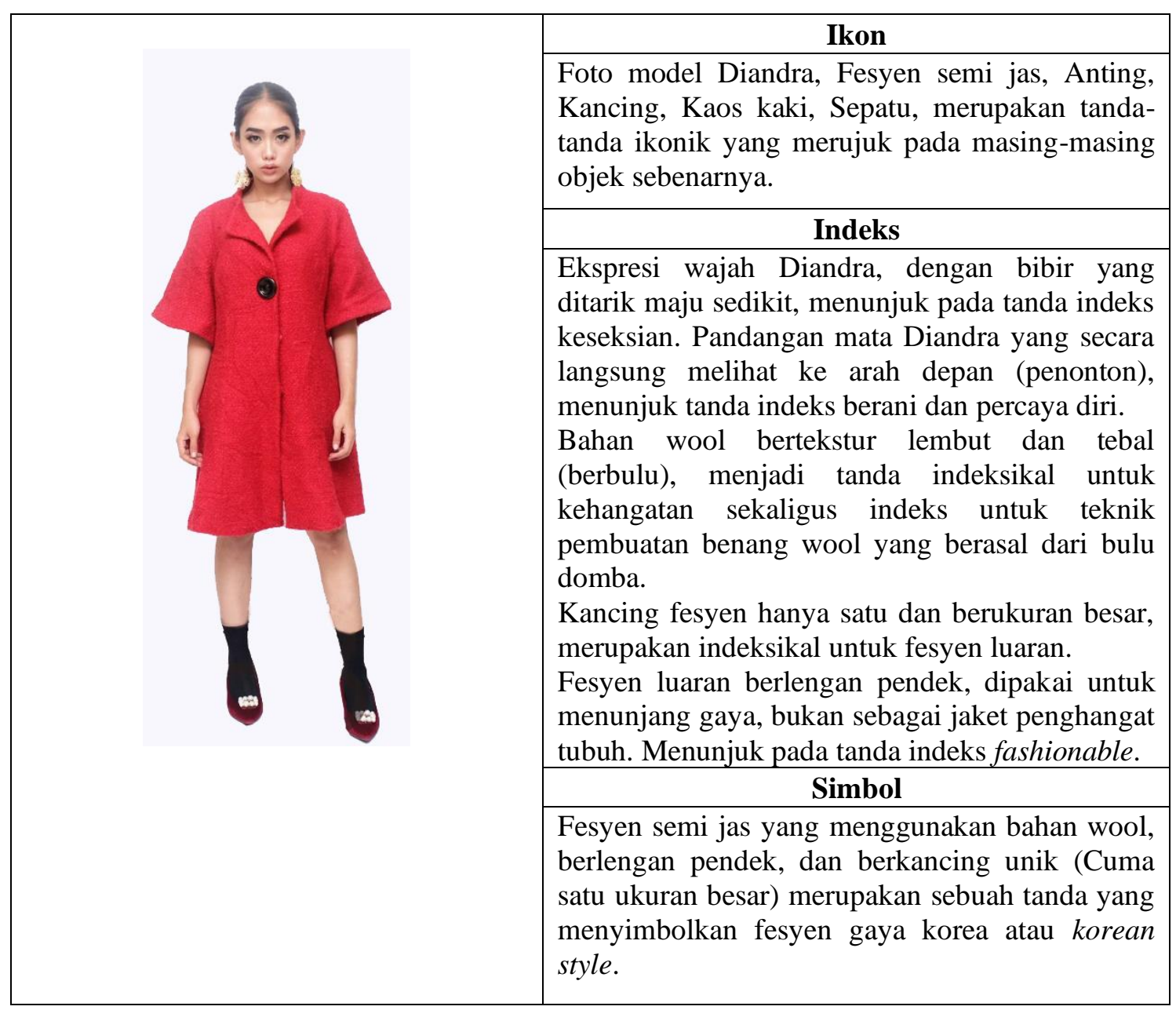


Sebagai sebuah fesyen pendukung (luaran/jaket), fesyen semi jas ini memiliki lengan pendek, dimana hal tersebut menunjukkan tanda tersendiri, yakni fashionable, aplikasi fungsinya yang lebih cenderung untuk menunjang gaya daripada penutup atau penghangat tubuh. Gaya lengan pendek ini biasanya akan digabung dengan fesyen lain di dalamnya (decker) atau fesyen utama kaos atau kemeja. Penggunaan kancing pada fesyen ini yang cukup menarik dan unik, ditambah dengan material kain wool dan warnanya yang merah menyala, menggiring pemikiran kepada fesyen gaya Korea atau Korean style. Pemikiran ini didukung dengan informasi yang berasal dari Le Budget yang mengatakan bahwa salah satu tempat asal koleksi baju bekasnya adalah dari Korea Selatan. Selain itu, secara keseluruhan tampilan, fesyen ini juga mengingatkan pada gaya fesyen Korean Style yang tengah tren di Indonesia beberapa tahun belakangan. Ditambah banyak artis-artis dalam negeri yang berkiblat ke negeri ginseng tersebut. Seiring gencarnya promosi dan ekspansi budaya pop (lebih dikenal dengan sebutan kpop) dan dunia hiburan Korea Selatan ke hampir seluruh dunia. Namun dibalik itu semua, penulis tertarik mengaitkan fesyen gaya k-pop ini dengan aspek ekspor budaya, yang dewasa ini semakin kentara dan mengental bersandingan dengan budaya dalam negeri.

K-pop adalah salah satu pesan verbal melalui media entertainmen. Indonesia salah satu negara yang terpengaruh sangat besar oleh budaya k-pop. Hal tersebut dapat ditunjukan dengan banyaknya boyband dan girlband yang meniru boyband dan girlband Korea Selatan. Tampaknya Korea Selatan mengikuti jejak dan belajar dari negara pendahulunya yang memasukan budaya mereka ke Indonesia, yaitu budaya Jepang. Sebelum merebaknya demam k-pop, j-pop (budaya pop Jepang) sudah lebih dahulu masuk ke Indonesia dan menciptakan dampak seperti Korea Selatan saat ini. Korea Selatan muncul dengan tampilan yang lebih segar dan dinamis dengan teknologi yang lebih canggih dan perkembangan media yang lebih maju. Kebangkitan teknologi dan penjualan produk elektronik, artis, film, musik, dan lain-lain saling mendukung, sehingga mampu menjadikan Korea Selatan semakin berkembang dan maju, dan menjadikan jalurnya lebih mudah untuk menguasai pasar dunia.

Dalam perspektif kebudayaan, ini akan sangat menjadi ancaman terhadap kebudayaan asli Indonesia. Hal tersebut menyebabkan ketidakstabilan budaya di Indonesia, karena anak mudanya lebih tertarik dengan kebudayaan negara lain dan cenderung lebih bangga dibanding dengan budaya negara sendiri. K-pop sasaran utamanya adalah remaja yang tingkat kestabilan emosinya masih labil, sehingga akan sangat mudah terpengaruh. Jika tidak segera ditanggulangi, lalu bagaimana nasib kebudayaan negara asli jika anak mudanya lebih cinta terhadap kebudayaan asing?

\section{Kode Kultural Fesyen Baju Bekas Le Budget}

Dalam kegiatan koleksi dan jual-belinya, Le Budget memanfaatkan fenomena konsumerisme jaman sekarang. Konsumerisme adalah salah satu buah dari perkembangan industri kapitalisme yang menghalalkan kegiatan konsumsi secara konstan dan aktif. Kegiatan konsumsi yang awalnya sederhana hanya sebagai pemenuhan akan kebutuhan, telah berubah menjadi sepenuhnya sebagai cara untuk membentuk identitas individu dalam masyarakat. Beragam gaya hidup terbentuk dan menuntut untuk selalu dihidupi dan dipenuhi secara konsumtif. Sifat dasar manusia 
untuk selalu ingin menonjolkan identitas pribadinya dalam kehidupan sosial, telah menggiring manusia bertindak berlebihan dalam mengkonsumsi barang demi mencapai tujuan tersebut.

Hal tersebut membuat manusia, secara sadar atau tidak, melekatkan nilai-nilai mistis pada barang-barang mati yang dianggap dapat menunjukkan identitas pribadinya. Komoditi fetitisme, istilah Karl Marx untuk konsep tersebut, membawa orang-orang pada suatu rasa keterikatan serta ketergantungan terhadap sebuah barang sebagai pengguna yang juga mengusahakan sebuah identitas yang dibentuk dalam tampilan yang dihadirkan. Hal ini pada akhirnya menyuburkan gaya hidup konsumtif menjadi jauh lebih besar daripada sebelumnya. Fesyen sebagai tampakan paling awal untuk menjelaskan dan menegaskan gaya hidup apa yang dimiliki seseorang, pada sisi lain adalah merupakan sesuatu yang dibentuk sedemikian rupa untuk menimbulkan kesan yang diinginkan. Fesyen merupakan gaya hidup sekaligus alat untuk membentuk gaya hidup itu sendiri. Gaya hidup (lifestyle) secara sosiologis (dengan pengertian terbatas) merujuk pada gaya hidup khas suatu kelompok tertentu (Featherstone, 2001). Sementara dalam masyarakat modern, gaya hidup (lifestyle) membantu mendefinisikan mengenai sikap, nilai-nilai, kekayaan, serta posisi sosial seseorang (Chaney, 2004). Dalam masyarakat modern istilah ini mengkonotasikan individualisme, ekspresi diri, serta kesadaran diri untuk bergaya. Tubuh, busana, cara bicara, hiburan saat waktu luang, pilihan makanan dan minuman, rumah, kendaraan, bahkan pilihan sumber informasi, dan seterusnya dipandang sebagai indikator dari individualistis selera, serta rasa gaya dari seseorang.

Fesyen baju bekas Le Budget pun mengambil bagian dalam pertarungan gaya hidup ini. Fenomena eksistensi Le Budget merupakan wujud ketidakpuasan orang (pengguna pakaian bekas) terhadap fesyen arus utama yang mendominasi pasaran. Karakter sistem fesyen arus utama adalah kecepatan produksi dan konsumsinya. Pakaian didesain untuk diproduksi secara besar-besaran, didistribusikan secara cepat, mudah berganti tren/model, dan dikonsumsi dalam kuantitas yang tinggi. Pakaian didesain untuk mengakomodir gaya hidup konsumtif. Melalui pengalaman sehari-hari, orang-orang melihat gaya hidup yang ditampilkan di media dan memilih gaya hidup mana yang menurutnya paling sesuai dengan dirinya, atau lebih tepatnya gaya hidup mana yang ingin dia penuhi untuk menjadi bagian dari gaya hidup tersebut.

Produksi barang secara besar-besaran tersebut mau tidak mau membutuhkan bahan baku, dan bahan baku tersebut adalah sesuatu yang diambil dari alam. Konsumerisme, mau tidak mau akan mendukung ekploitasi terhadap sumber daya alam, karena itulah satu-satunya sumber bagi segala bahan baku yang dibutuhkan untuk produksi. Penggunaan sumber daya alam ini, tidak terbatas hanya pada sumber daya alam yang dapat diperbaharui, namun juga mengambil sumber daya alam yang tidak dapat diperbaharui. Hal ini tentu saja, pada titik tertentu menimbulkan kekhawatiran terhadap keberlangsungan hidup makhluk dan segala elemen yang mendukung kehidupan yang layak di bumi. Kegiatan mengkonsumsi barang-barang yang merupakan kebutuhan primer, sekunder maupun tersier dalam skala yang berlebihan akan membawa manusia pada sebuah kenyataan akan pengrusakan bagian-bagian tertentu alam untuk mempertahankan kegiatan produksi yang berorientasi untuk memperoleh keuntungan. Setelah barang-barang tersebut tidak lagi dapat memenuhi nilai gunanya, ia akan berakhir menjadi sampah yang menumpuk. Sampah tersebut 
kemudian menjadi sebuah masalah baru yang berakibat fatal terhadap kelestarian lingkungan.

Dalam konteks permasalahan seperti itu, fesyen baju bekas Le Budget memegang peranan cukup penting sebagai sebuah metode untuk meminimalisir kerusakan yang disebabkan sebagai bencana konsumerisme. Fesyen baju bekas Le Budget sebagai sebuah upaya yang dilakukan secara terus menerus sebagai bentuk perlawanan terhadap budaya konsumtif yang menjamur di kalangan masyarakat, khususnya masyarakat perkotaan yang memiliki obsesi tak terbendung terhadap perwujudan identitas yang berusaha mereka tampilkan pada apa yang mereka kenakan dan mereka konsumsi. Semangat perlawanan fesyen baju bekas Le Budget adalah sesuatu yang membuatnya eksis bertahan hingga saat ini. Upaya untuk menekan konsumsi dengan mengenakan kembali atau menggunakan ulang pakaian-pakaian yang masih layak pakai adalah sebuah cara untuk memberikan solusi terhadap permasalahan yang ditimbulkan budaya konsumtif. Melalui fesyen-fesyen baju bekasnya, Le Budget meletakkan nilai-nilai yang dapat dilihat sebagai sebuah bentuk protes terhadap budaya konsumerisme yang mengkonsumsi tanpa putus dan sebuah kampanye kecil-kecilan terhadap kelestarian lingkungan.

Fesyen baju bekas Le Budget mencoba menujukkan diri sebagai salah satu solusi yang mungkin dilakukan untuk meminimalisir dampak limbah tekstil. Hal ini dapat dilihat sebagai sebuah kemungkinan lain dalam menghadapi dampak limbah tekstil, bahwa membuangnya ke tempat sampah bukan satu-satunya pilihan. Justru akan menimbulkan permasalahan baru. Fesyen baju bekas Le Budget memegang peranan sebagai sebuah instrumen untuk mengkampanyekan semangat tersebut kepada masyarakat yang lebih luas. Le Budget mencoba menjadi sebuah gerakan independen untuk tidak terlibat sepenuhnya dalam perputaran budaya populer yang secara aktif menghadirkan tren-tren untuk dikonsumsi, dimiliki dan diminati pada sebuah periode tertentu hingga tergantikan dengan tren-tren lain dengan tujuan serupa.

\section{KESIMPULAN}

Pengaruh fesyen baju bekas Le Budget dalam ranah industri kreatif adalah mampu membuka ruang untuk kreatifitas yang diwujudkan dalam bentuk item fesyen sebagai alat atau cara untuk merepresentasikan ekspresi individual. Fesyen baju bekas Le Budget menegaskan kekuatannya sebagai sebuah fesyen alternatif yang tidak hanya menjadi sebuah penjelas identitas sang pemakai, namun juga sebagai cara untuk menunjukkan keadaan yang sedang berlangsung di lingkungan sekitar. Inilah kekuatan utama dari fesyen baju bekas Le Budget, yakni reuse-reduce-reproduce.

Kemampuannya sebagai komunikasi non-verbal, fesyen baju bekas Le Budget digunakan sebagai instrumen untuk menyuarakan kampanye terhadap masalah-masalah lingkungan (limbah tekstil) dan konsumsi masyarakat budaya populer, sekaligus menjadi alternatif solusi pada saat yang bersamaan. Sebagai sebuah produk kebudayaan, dalam konteks ini budaya minoritas, fesyen baju bekas Le Budget bertindak bukan hanya sebagai produk hasil dari kebudayaan yang melahirkannya, namun juga sebagai sebuah strategi untuk menentukan posisi budaya tanding fesyen baju bekas Le Budget tersebut dalam kebudayaan secara keseluruhan dalam menghadapi era industri kreatif. 


\section{DAFTAR PUSTAKA}

Barnard, M. (2011). Fashion as Communication (Fashion sebagai Komunikasi Cara Mengkomunikasikan Identias Sosiasl, Seksual, Kelas dan Gender), diterjemahkan oleh Idy Subandy Ibrahim. Jalasutra. Yogyakarta.

Chaney, D. (2004). Lifestyle Sebuah Pengantar Komprehensif. Yogyakarta: Jalasutra.

Elsner, J. (1994). The Culture of Collecting. Massachusetts: Harvard University Press.

Featherstone, M. (2001). Postmodernisme dan Budaya Konsumen. Yogyakarta: Pustaka Pelajar.

Miles, M.B \& Huberman, A.M. (1992). Qualitative Data Analysis. Analisis Data Kualitatif: Buku Sumber Tentang Metode-Metode Baru, diterjemahkan oleh Tjetjep Rohendi Rohadi. Penerbit UI Press. Jakarta.

Pilliang, Y.A. (2012). Semiotika dan Hipersemiotika: Kode, Gaya, \& Matinya Makna. Jakarta Selatan: Matahari.

Sunhilde, C. (2012). Fast Fashion and Secondhand Clothes Between Ecological Concern and Global Business. Annals of The University of Oradea Fascicle of Textiles, Leatherwork. Romania: University of Oradea. 